\title{
Older workers' withdrawal from the labour market 1991 to 2007: impact of socio-demographic characteristics, health and household circumstances
}

\author{
Ercilia Dini \\ Office for National Statistics
}

\begin{abstract}
This article presents an analysis of the withdrawal from the labour market of older workers in England and Wales between 1991 and 1995 and in England between 2002/03 and 2006/07. It examines the relationship between withdrawal from the labour market and demographic and socio-economic characteristics of older workers, their labour market status, health status, housing, household circumstances and caring commitments at the start of each period being considered.
\end{abstract}




\section{Contents}

Older workers' withdrawal from the labour market 1991 to 2007: impact of sociodemographic characteristics, health and household circumstances

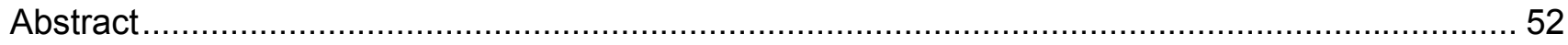

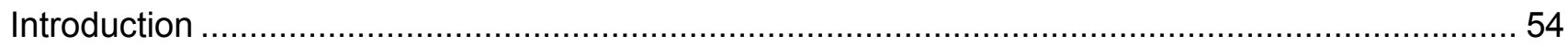

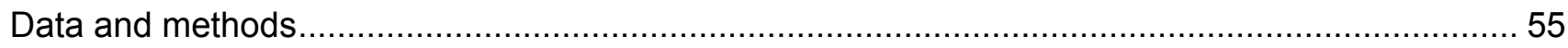

Withdrawal from the labour market in the early 1990s and 21st century: relationship with demographic characteristics, household, health and caring ……............................................. 57

Withdrawal from the labour market and net impact of factors: logistic regression analysis ............ 64

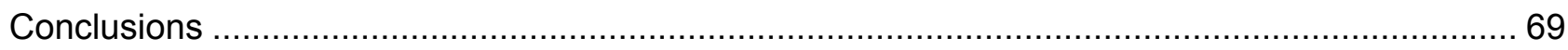

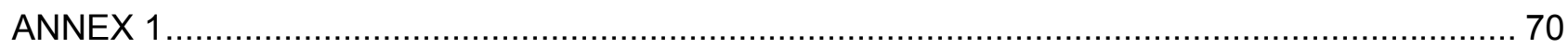

ANNEX 2

ANNEX 3 ……

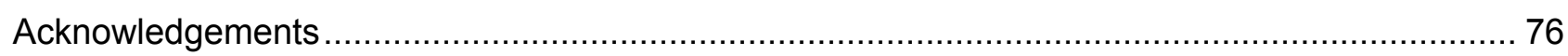

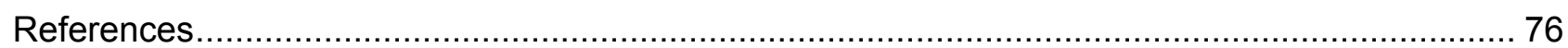




\section{Introduction}

In the UK in 2009 there were 28.9 million people in the age group 16 to 49 (47 per cent of the population) and 11.2 million people aged 50 to 64 (18 per cent of the population). In the next 25 years the percentage of people aged 16 to 49 is projected to decrease by four per cent and, although the percentage of people aged 50 to 64 and 65 to 68 are projected to remain broadly constant at about 18 and 5 per cent respectively, there will be an increase of about 1.7 million people in the age group 50 to 68 (to a population of 15.2 million). The greatest increase however, in both absolute number and percentage of population, will be among people aged 69 and over (from 13 to 19 per cent; an absolute increase of 5.6 million to a population of 13.4 million).

This shift towards an older population affects the size and composition of the labour force and increases pressures on pension provision. There has been a rise in employment rate among women and men aged 50 to 64 since the 1990s. Despite this increase, in 2010, two-fifths of women and a quarter of men of this age were economically inactive. The main reasons for economic inactivity were retirement for women and sickness or disability for men (Figure 1).

\section{Figure 1 Women and men aged 50-64 by economic activity status, 1995, 2000 and 2010, United Kingdom}

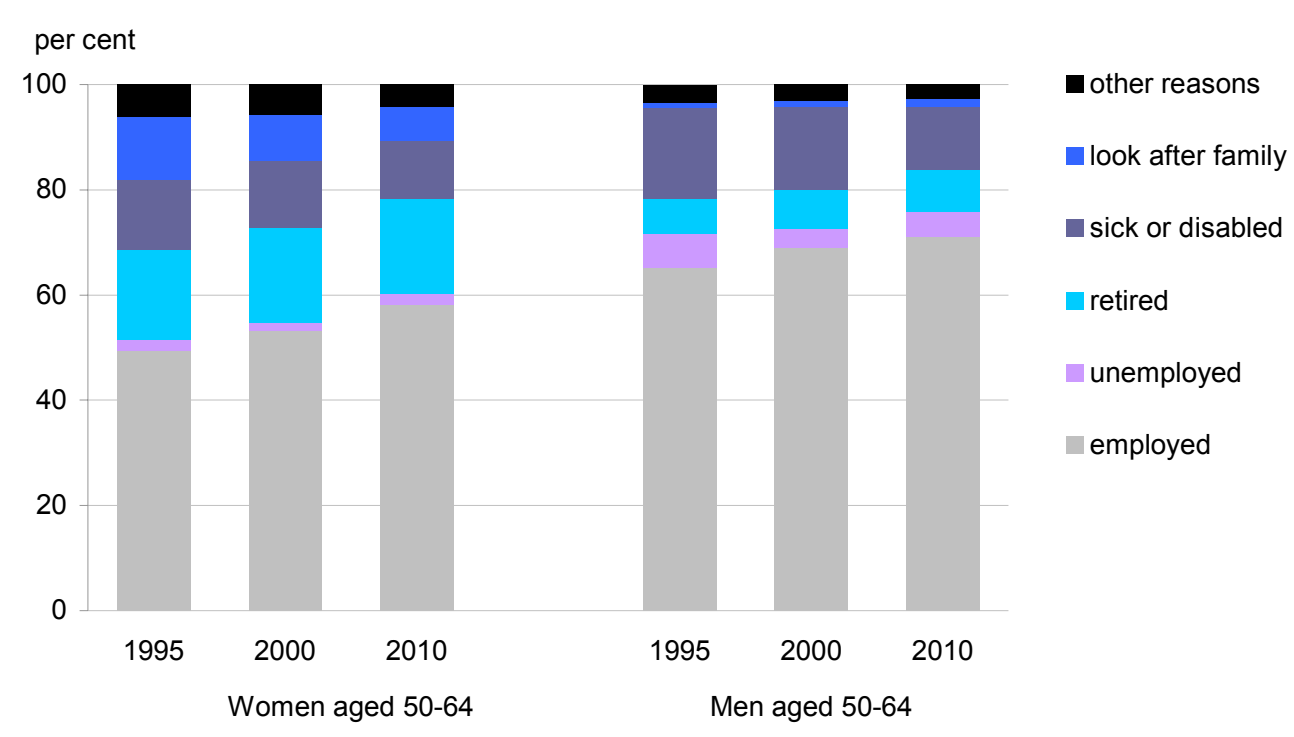

Source: LFS April-June quarter, 1995, 2000 and 2010, not seasonally adjusted

Research and statistics on the factors that may help or hinder extending working life beyond State Pension Age (SPA) are important to inform future policies on employment, unemployment and inactivity at older ages. At a seminar held by ONS in $2009^{1}$, delegates identified older workers and retirement as areas where more statistics and research were needed.

This article presents an analysis of the withdrawal from the labour market of older workers in England and Wales between 1991 and 1995 and in England between 2002/03 and 2006/07. It examines the relationship of withdrawal from the labour market with demographic and socioeconomic characteristics of older workers, their labour market status, health status, housing, household circumstances and caring commitments at the start of each period being considered. 


\section{Data and methods}

Data from the ONS Longitudinal Study (ONS LS) $)^{2}$ were used to investigate the withdrawal from the labour market between 1991 and 1995 of women and men aged 50 to 64 in England and Wales in 1991 and the factors related to it.

Withdrawal from the labour market was defined as the change in economic activity status from being economically active (employed full- or part-time or unemployed) at the start of the period to being economically inactive (because of retirement or sickness/disability or to look after family or for other reasons) at the end of the period.

The ONS LS contains linked decennial census data. To investigate withdrawal from the labour market between years 1991 and 1995, a proxy variable was created using people's economic activity statuses recorded at censuses in 1991 and 2001, and the 2001 Census question 'last year worked' (Box 1). Annex 1 provides more information on the ONS LS data source, as well as definitions of economic activity status in 1991 and 2001 censuses and of the demographic and socio-economic characteristics, health status, housing and household circumstances used in the analysis.

Data from the English Longitudinal Study of Ageing (ELSA) ${ }^{3}$ were used to investigate the withdrawal from the labour market between 2002/03 and 2006/07 of women and men aged 50 to 64 in England in 2002/03, and the factors related to it. Annex 2 contains information about ELSA, definitions of economic activity status and of the demographic and socio-economic characteristics, health status, housing and caring commitments used in the analysis.

Annex 3 contains the main differences between the ONS LS and ELSA data sources and includes procedures carried out to check potential effects that any differences could have on the results.

For the analysis the ONS LS sample was divided into two groups: a group of people aged 50 to 64 in 1991 who withdrew from the labour market between 1991 and 1995 (12,826 people) and a reference group formed by people of the same age who had not withdrawn from the labour market in the same period (24,678 people). The ELSA sample of core members was divided into two groups: a group of people who withdrew from the labour market between 2002/03 and 2006/07 (669 people) and a reference group who had not withdrawn from the labour market in this period (1,965 people).

Logistic regression was used to investigate the probability of withdrawal from the labour market in each period, taking into account a range of demographic and socio-economic factors, health and household circumstances. Initially bivariate analyses were conducted. Factors that showed differences statistically significant at the 95 per cent level were then entered into a stepwise multivariate logistic regression analysis, conducted for women and men separately. 


\section{Box one ONS LS proxy for withdrawal from the labour market between 1991 and 1995}

Information on the economic activity status recorded in the 1991 and 2001 censuses and the 2001 Census question 'Last year worked' were used to create a proxy variable for the withdrawal from the labour market between 1991 and 1995. People who were economically active in census 1991 and economically inactive in census 2001 and who had answered in census 2001 that 'last year worked' had been between 1991 and 1995 were considered as having left the labour market in the period 1991 to 1995. People who were active in 1991 and inactive in 2001 and had answered that 'last year worked' was between 1996 and 2001, and people who were active in 1991 and in 2001, were considered as economically active in the period 1991 to 1995. The diagram below illustrates the method used to create the proxy variable for the withdrawal from the labour market in this period.

\section{Diagram 1 Method used to derive a proxy variable for withdrawal from the labour market between 1991 and 1995}

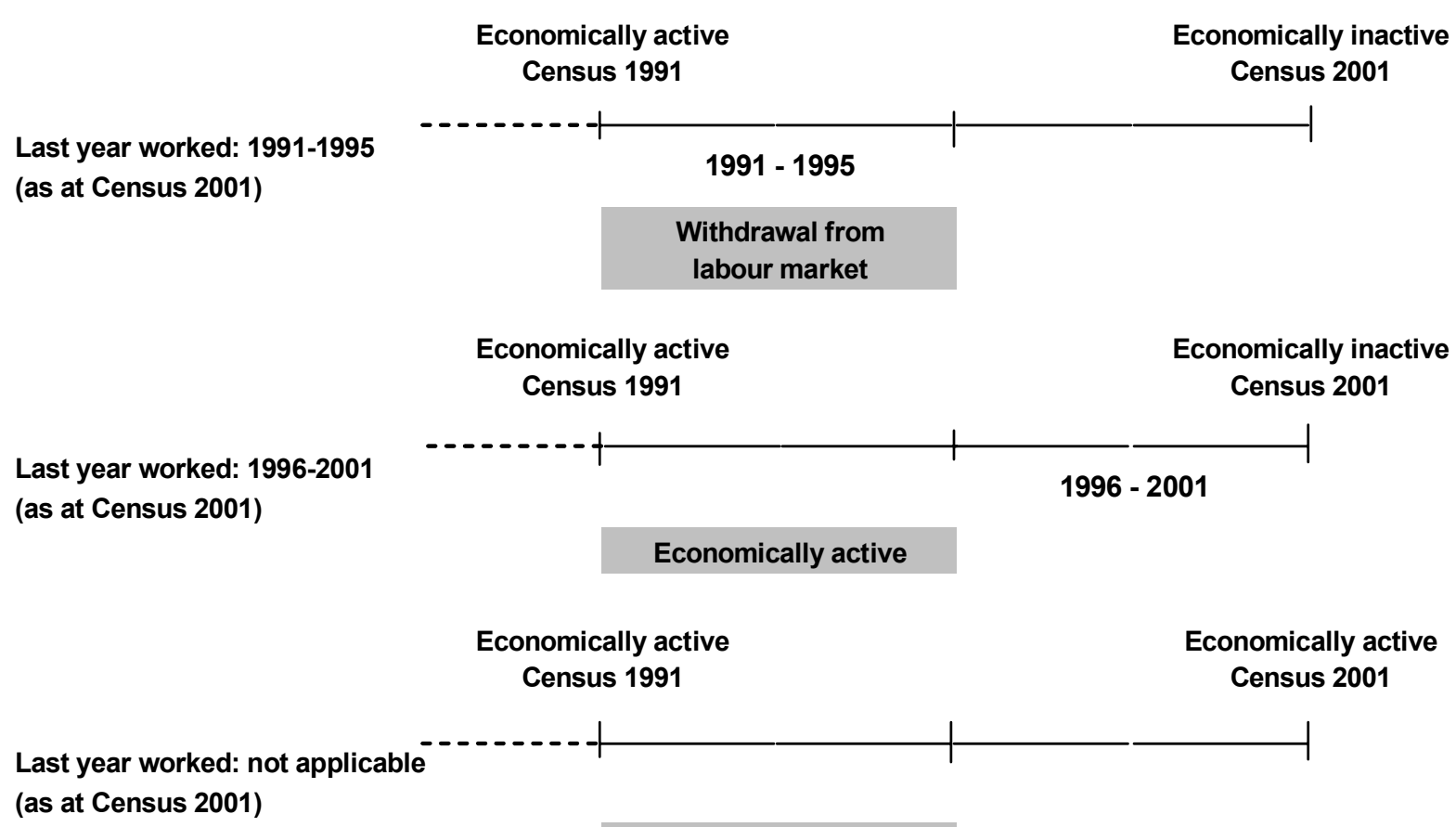

Economically active 
Tables 1 and 2 summarise sample sizes and percentages of women and men by age group and economic activity status in the periods 1991 to 1995, 2002/03 and 2006/07 respectively.

\section{Table $1 \quad$ Women and men by age group and economic activity

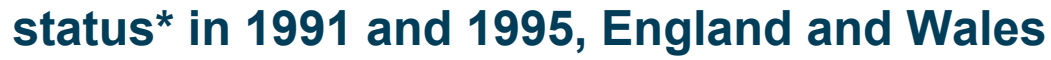

\begin{tabular}{|c|c|c|c|c|c|c|}
\hline \multirow[b]{3}{*}{$\begin{array}{l}\text { Age in } \\
1991\end{array}$} & \multicolumn{6}{|c|}{ Economic activity status in 1991 and 1995} \\
\hline & \multicolumn{2}{|c|}{ Women } & \multicolumn{4}{|c|}{ Men } \\
\hline & $\begin{array}{r}\text { per cent } \\
\text { active in } 1991 \\
\text { and inactive in } \\
1995 \\
\end{array}$ & $\begin{array}{r}\text { per cent } \\
\text { active in } 1991 \\
\text { and active in } \\
1995 \\
\end{array}$ & women & $\begin{array}{r}\text { per cent } \\
\text { active in } 1991 \\
\text { and inactive in } \\
1995 \\
\end{array}$ & $\begin{array}{r}\text { per cent } \\
\text { active in } 1991 \\
\text { and active in } \\
1995 \\
\end{array}$ & men \\
\hline $50-54$ & 22 & 78 & 7,627 & 15 & 85 & 11,902 \\
\hline $55-59$ & 50 & 50 & 5,137 & 35 & 65 & 10,716 \\
\hline $60-64$ & 63 & 37 & 1,880 & 68 & 32 & 9,116 \\
\hline
\end{tabular}

Source: ONS LS 1991 and 2001

*Note:

Economic activity status: 'active' refers to people in full- or part-time employment or unemployed; 'inactive' refers to those who are retired or inactive because of sickness/disability or to look after family or for other reasons.

Economically active in 1991 and inactive in 1995 denotes withdrawal from the labour market.

\section{Table $2 \quad$ Women and men by age group and economic activity}

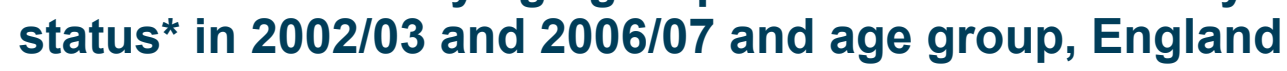

\begin{tabular}{|c|c|c|c|c|c|c|}
\hline & \multicolumn{6}{|c|}{ Economic activity status in $2002 / 03$ and $2006 / 07$} \\
\hline & \multicolumn{2}{|c|}{ Women } & \multicolumn{4}{|c|}{ Men } \\
\hline $\begin{array}{l}\text { Age in } \\
2002-03\end{array}$ & $\begin{array}{r}\text { per cent } \\
\text { active in 2002- } \\
03 \& \text { inactive } \\
\text { in } 2006-07\end{array}$ & $\begin{array}{r}\text { per cent } \\
\text { active in 2002- } \\
03 \& \text { active in } \\
2006-07\end{array}$ & women & $\begin{array}{r}\text { per cent } \\
\text { active in 2002- } \\
03 \& \text { inactive } \\
\text { in } 2006-07\end{array}$ & $\begin{array}{r}\text { per cent } \\
\text { active in } \\
2002-03 \text { \& } \\
\text { active in } \\
2006-07\end{array}$ & men \\
\hline $50-54$ & 12 & 88 & 598 & 9 & 91 & 546 \\
\hline $55-59$ & 37 & 63 & 505 & 21 & 79 & 529 \\
\hline $60-64$ & 51 & 49 & 186 & 56 & 44 & 270 \\
\hline
\end{tabular}

Source: ELSA 2002/03 and 2006/07

*Note:

Economic activity status: 'active' refers to people in full- or part-time employment or unemployed; 'inactive' refers to those who are retired or inactive because of sickness/disability or to look after family or for other reasons.

Economically active in 2002/03 and inactive in 2006/07 denotes withdrawal from the labour market.

\section{Withdrawal from the labour market in the early 1990s and 21st century: relationship with demographic characteristics, household, health and caring}

Figure 2 shows the percentage of women and men who withdrew from the labour market in England and Wales between 1991 and 1995 and in England between 2002/03 and 2006/07, for age groups 50 to 54,55 to 59 and 60 to 64 at the start of each period.

Unsurprisingly, the percentage of women and men who withdrew from the labour market increased with age and this was observed in both periods. However, the percentage of both women and men 
who withdrew from the labour market between 2002/03 and 2006/07 was lower than the percentage of people who had left the labour market about a decade earlier. This was the case whichever age group was considered. For ages 60 to 64 the percentages of women and men who withdrew from the labour market between 2002/03 and 2006/07 were 12 percentage points lower than the percentage of people in that age group who had withdrawn from the labour market in the early 1990s.

\section{Figure 2 Women and men who withdrew* from the labour market in England and Wales between 1991 and 1995 and in England between $2002 / 03$ and 2006/07 by age group at the start of each period}

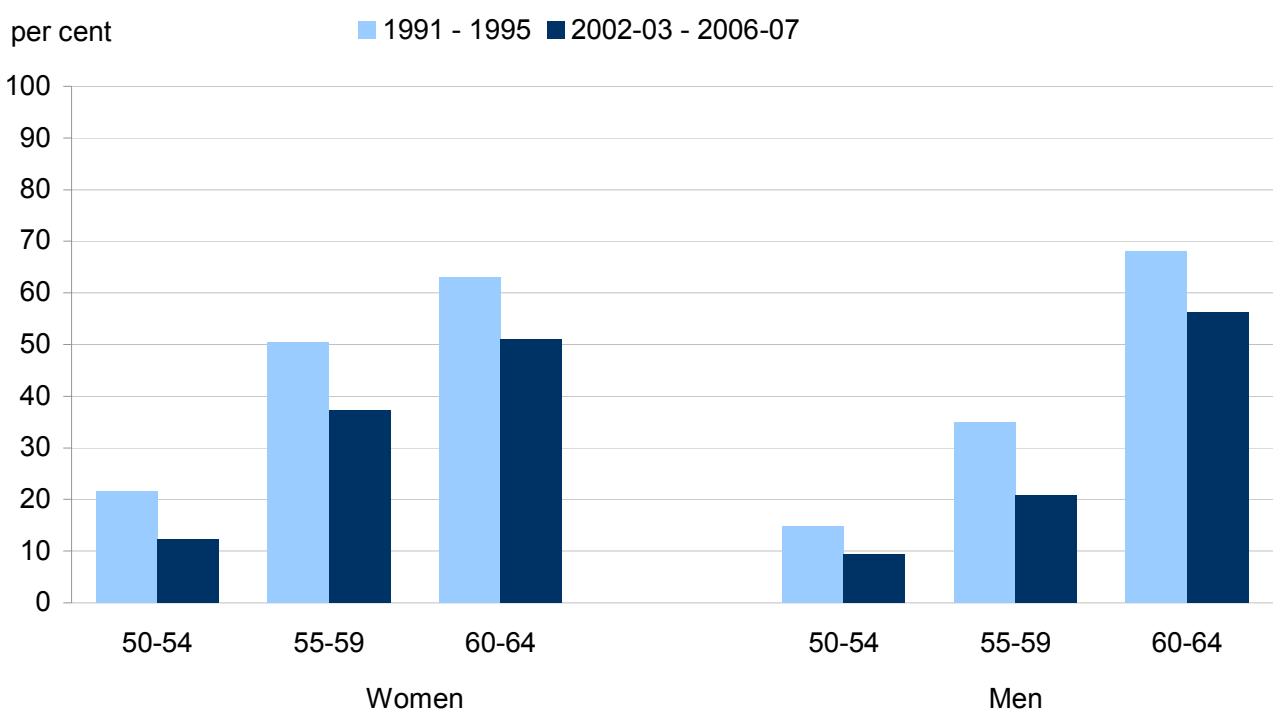

Source: ONS LS 1991 and 2001, ELSA 2002/03 and 2006/07

*Note:

Withdrawal from the labour market: refers to people who were economically active (full- or part time employed or unemployed) at the start of the period and economically inactive (because of retirement or sickness/disability or to look after family or for other reasons) at the end of the period.

Withdrawal from the labour market: association with demographic characteristics, health status, household circumstances and caring commitments

\section{Ethnicity and marital status}

Table 3 presents the percentage of women and men aged 50 to 64 in 1991 who withdrew from the labour market between 1991 and 1995, by ethnic group. About 40 per cent of the economically active Indian, Pakistani or Bangladeshi women aged 50 to 64 in 1991 left the labour market between 1991 and 1995. This percentage was higher than the percentage of women in any other ethnic group who left the labour market in the same period. Among men, the ethnic group with the highest percentage exiting the labour market in this period was the White British (32.8 per cent). 


\section{Table $3 \quad$ Withdrawal from the labour market* between 1991 and 1995 by ethnic group, women and men aged 50 to 64 in 1991, England and Wales}

\begin{tabular}{|c|c|c|c|c|c|c|}
\hline \multirow{4}{*}{ Ethnic group } & \multicolumn{6}{|c|}{ Withdrawal from labour market 1991-1995 } \\
\hline & \multicolumn{2}{|c|}{ Women } & \multicolumn{4}{|c|}{ Men } \\
\hline & Yes** & No & & Yes $^{* *}$ & No & \\
\hline & per cent & per cent & number & per cent & per cent & number \\
\hline White British & 37.3 & 62.7 & 13,638 & 32.8 & 67.2 & 20,940 \\
\hline Irish and Other White & 32.8 & 67.2 & 577 & 28.5 & 71.5 & 825 \\
\hline $\begin{array}{l}\text { Black Caribbean, Black African, } \\
\text { Mixed and Other ethnic groups }\end{array}$ & 30.1 & 69.9 & 256 & 26.3 & 73.7 & 468 \\
\hline Indian, Pakistani, Bangladeshi & 39.3 & 60.7 & 173 & 27.6 & 72.4 & 627 \\
\hline
\end{tabular}

Source: ONS LS 1991 and 2001

Notes:

*Withdrawal from the labour market: refers to people who were economically active (full- or part-time employed or unemployed) in 1991 and economically inactive (because of retirement or sickness/disability or to look after family or for other reasons) in 1995

${ }^{* *}$ Association between withdrawal from the labour market and ethnic group: for women $p=0.014$; for men $p<0.001$

\section{Table $4 \quad$ Withdrawal from the labour market* in England and Wales between 1991 and 1995 and in England between 2002/03 and $2006 / 07$ by marital status. Women and men aged 50 to 64 at the start of each period}

\begin{tabular}{|c|c|c|c|c|c|c|}
\hline \multirow{3}{*}{$\begin{array}{l}\text { Period of withdrawal } \\
\text { and marital status at } \\
\text { start of each period }\end{array}$} & \multicolumn{6}{|c|}{ Withdrawal from labour market } \\
\hline & \multicolumn{3}{|c|}{ Women } & \multicolumn{3}{|c|}{ Men } \\
\hline & $\begin{array}{r}\text { Yes } \\
\text { per cent }\end{array}$ & $\begin{array}{r}\text { No } \\
\text { per cent }\end{array}$ & number & $\begin{array}{r}\text { Yes } \\
\text { per cent }\end{array}$ & $\begin{array}{r}\text { No } \\
\text { per cent }\end{array}$ & number \\
\hline \multicolumn{7}{|l|}{ 1991-1995 } \\
\hline Married/remarried & 37 & 63 & 11,315 & 32 & 68 & 20,004 \\
\hline Single & 48 & 52 & 720 & 36 & 64 & 1,154 \\
\hline Divorced & 30 & 70 & 1,415 & 26 & 74 & 1,274 \\
\hline Widowed & 42 & 58 & 1,194 & 46 & 54 & 428 \\
\hline \multicolumn{7}{|l|}{ 2002-03 and 2006-07 } \\
\hline Married/remarried & 28 & 72 & 916 & 23 & 77 & 1,074 \\
\hline Single & 19 & 81 & 57 & 28 & 73 & 80 \\
\hline Divorced & 23 & 77 & 245 & 21 & 79 & 155 \\
\hline Widowed & 39 & 61 & 71 & 40 & 60 & 35 \\
\hline
\end{tabular}

Source: ONS LS 1991 and 2001, ELSA 2002/03 and 2006/07

*Notes:

Withdrawal from the labour market: refers to people who were economically active (full- or part-time employed or unemployed) at the start of the period and were economically inactive (because of retirement or sickness/disability or to look after family or for other reasons) at the end of the period

Period 1991 to1995: association between withdrawal from the labour market and marital status; for women and men $\mathrm{p}<$ 0.001

Period 2002/03 and 2006/07: association between withdrawal from the labour market and marital status; for women $p=$ 0.018 ; for men $p=0.078$ 
Table 4 shows the percentage of women and men aged 50 to 64 in 1991 and in 2002/03 who withdrew from the labour market between 1991 and 1995 and between 2002/03 and 2006/07 by marital status.

Marital status affected exit from the labour market in both periods. Women and men who were married or divorced were less likely to have left the labour market between 1991 and 1995 compared with single or widowed people. The relationship between withdrawal of men from the labour market between 2002/03 and 2006/07 and their marital status was similar to that of the earlier period. Married or divorced men were less likely to exit the labour market compared with single or widowed men. For women the relationship was different: women who were single were less likely than women of any other marital status to have left the labour market between 2002/03 and 2006/07. However, interpretation of this relationship should be made with caution because of a small ELSA sample size.

For both periods age can be a confounding factor in the relationship between withdrawal from the labour market and marital status. The age group under investigation (50 to 64) is broad and it may be that women and men who are widowed are generally older than married or divorced people.

\section{Health status}

Over the age of 50 years the main barriers to working longer are ill-health and disability. Data published by ONS show that while both life expectancy and healthy life expectancy (years of expected life in good or fairly good health) are increasing, the gap between the two measures is widening ${ }^{4}$. Withdrawal from the labour market in England and Wales
between 1991 and 1995 and in England between 2002/03
and $2006 / 07$ by self-reported health status. Women and
men aged 50 to 64 at the start of each period

\begin{tabular}{|c|c|c|c|c|c|c|}
\hline \multirow{3}{*}{$\begin{array}{l}\text { Period of withdrawal and self- } \\
\text { reported health status at start of } \\
\text { each period }\end{array}$} & \multicolumn{6}{|c|}{ Withdrawal from labour market } \\
\hline & \multicolumn{3}{|c|}{ Women } & \multicolumn{3}{|c|}{ Men } \\
\hline & $\begin{array}{r}\text { Yes } \\
\text { per cent }\end{array}$ & $\begin{array}{r}\text { No } \\
\text { per cent }\end{array}$ & women & $\begin{array}{r}\text { Yes } \\
\text { per cent }\end{array}$ & $\begin{array}{r}\text { No } \\
\text { per cent }\end{array}$ & men \\
\hline \multicolumn{7}{|l|}{ 1991-1995 } \\
\hline Has a health problem & 49 & 51 & 814 & 49 & 51 & 1,430 \\
\hline Does not have a health problem & 36 & 64 & 13,830 & 31 & 69 & 21,430 \\
\hline \multicolumn{7}{|l|}{ 2002-03 and 2006-07 } \\
\hline Fair, bad or very bad & 36 & 64 & 271 & 26 & 74 & 318 \\
\hline Very good or good & 23 & 77 & 363 & 20 & 80 & 365 \\
\hline
\end{tabular}

Source: ONS LS 1991 and 2001, ELSA 2002/03 and 2006/07

*Notes:

Withdrawal from the labour market: refers to people who were economically active (full- or part-time employed or unemployed) at the start of the period and were economically inactive (because of retirement or sickness/disability or to look after family or for other reasons) at the end of the period

Period 1991 to1995: association between withdrawal from the labour market and self-reported health status; for women and for men $\mathrm{p}<0.001$

Period 2002/03 and 2006/07: association between withdrawal from the labour market and self-reported health status; for women $p<0.01$; for men $p=0.09$ 
Table 5 presents the effect that health may have on withdrawal of older workers from the labour market in both periods under investigation. Between 1991 and 1995, about half of women and men who at the start of the period had stated that they had a health problem, had withdrawn from the labour market by the end of that period compared with about a third of people who had not stated that they had a health problem at the start of the period, but who had also left the labour market by the end of that period.

Between 2002/03 and 2006/07, about a third of women and a quarter of men who had stated that they had a health problem at the start of the period, had withdrawn from the labour market by 2006/07. Smaller percentages of women (a quarter) and men (a fifth), who at the start of the period had stated that they had very good or good health had left the labour market in that period.

\section{Household circumstances and caring commitments}

Personal circumstances affect decisions to continue or to stop working. For couples it is likely that partners influence each other's decisions whether to continue working or become economically inactive. For example, married women may work longer because they plan to withdraw from the labour market at the same time as their husbands. Figure 3 shows that women and men whose spouse or partner was economically inactive at the start of the period were almost twice as likely to withdraw from the labour market by the end of the period compared with people whose spouse or partner was economically active at the start of the period.

\section{Figure 3 Withdrawal from the labour market* ${ }^{*}$ between 1991 and 1995 by economic activity status of spouse/partner in 1991, women and men aged 50 to 64 in 1991, England and Wales}

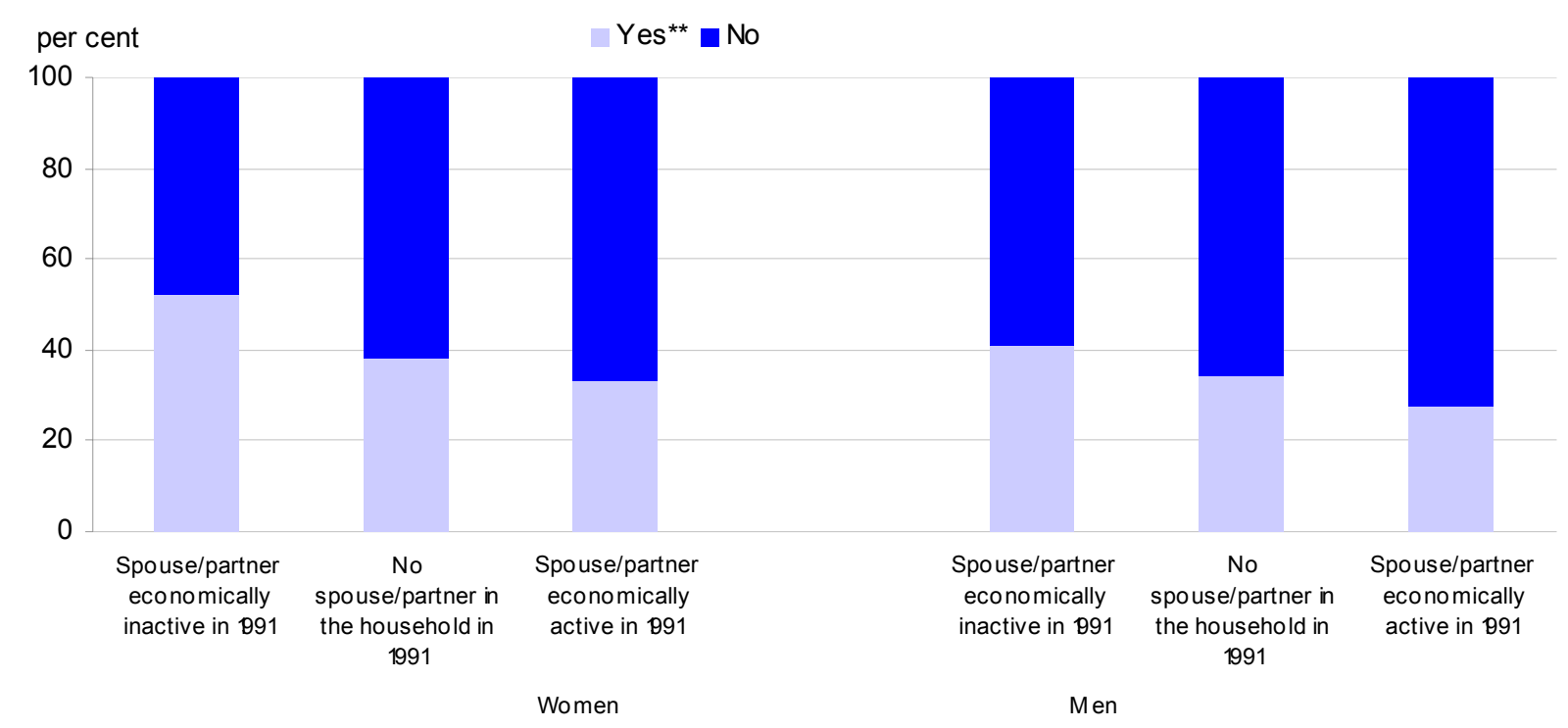

Source: ONS LS 1991 and 2001

Notes:

*Withdrawal from the labour market: refers to people who were economically active (full- or part-time employed or unemployed) in 1991 and economically inactive (because of retirement or sickness/disability or to look after family or for other reasons) in 1995

${ }^{* *}$ Association between withdrawal from the labour market and economic activity status of spouse/partner in 1991: for women and men $p<0.001$ 
The relationship between paid employment and caring commitments is complex. Caring provided by spouse or partner is likely to become increasingly important in the future given a decline in parent-child co-residence, improvements in male life expectancy and the increasing participation of women in the labour force. The increase in caring responsibilities for a partner, older relatives or grandchildren may make continuation of paid employment difficult.

Figure 4 shows the percentage of women and men aged 50 to 64 in 2002/03 who withdrew from the labour market between $2002 / 03$ and $2006 / 07$ by caring commitments in the week prior to being interviewed. Women who, at the start of the period, had stated that they had cared for someone in the week prior to being interviewed, were slightly more likely to withdraw from the labour market in the period, compared with women who had exited the labour market, despite not having stated caring commitments in the week prior to being interviewed. Among men, caring commitments did not seem to be related to exiting from the labour market in the period.

\section{Figure $4 \quad$ Withdrawal from the labour market* ${ }^{*}$ between 2002/03 and $2006 / 07$ by caring commitment in the week prior to interview, women and men aged 50 to 64 in 2002/03, England}

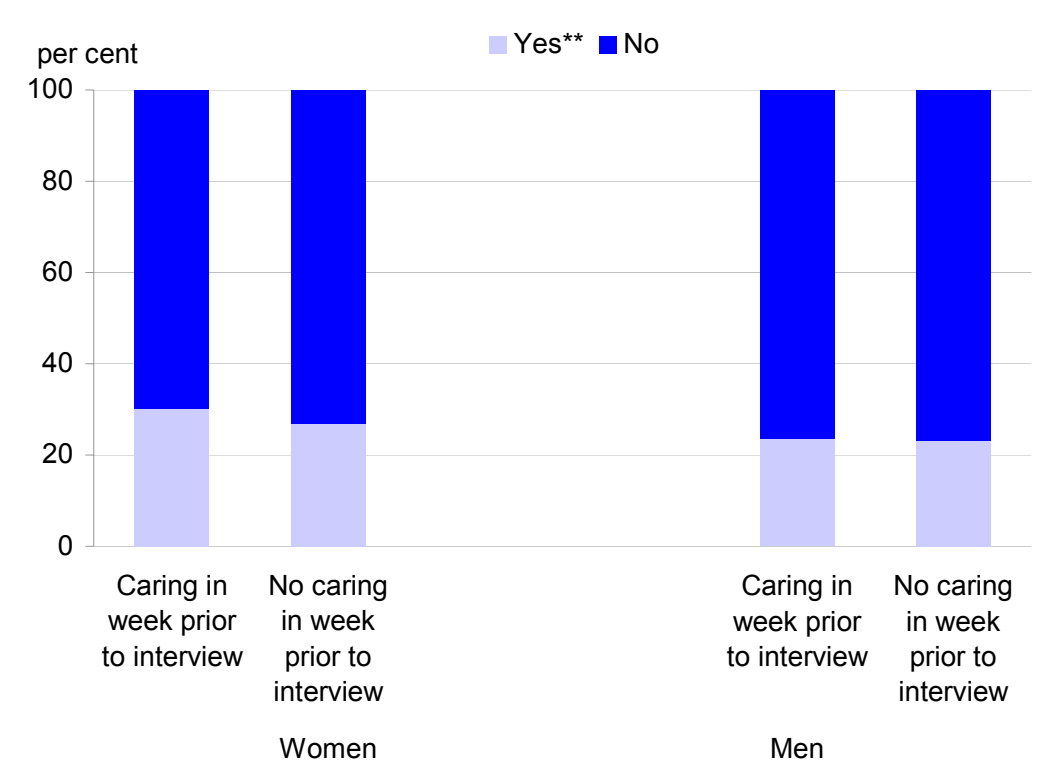

Source: ELSA 2002/03 and 2006/07

Notes:

*Withdrawal from the labour market: refers to people who were economically active (full- or part-time employed or unemployed) in 2002/03 and economically inactive (because of retirement or sickness/disability or to look after family or for other reasons) in 2006/07

** Association between withdrawal from the labour market and caring commitments in the week prior to being interviewed not statistically significant: for women $p=0.27$, for men $p=0.19$

The 1991 Census did not include a question on caring. As a proxy, analysis of withdrawal from the labour market between 1991 and 1995 and presence/absence of a member of the household with long-term illness at the start of the period was conducted (see Figure 5). This showed that women and men, who had one or more people with long-term illness in the household, or who were living alone, were more likely to withdraw from the labour market compared with those who had no people with long- term illness in the household. 
Furthermore, in the bivariate analysis, withdrawal of older workers from the labour market between 1991 and 1995 was significantly associated with highest qualification held, social class (based on occupation), labour market status at the start of the period, housing tenure, presence/absence of dependent child/children in the household and region of usual residence.

\section{Figure 5 Withdrawal from the labour market* between 1991 and 1995 by presence/absence of a member of the household with long term illness at the start of the period, women and men aged 50 to 64 in 1991, England and Wales}

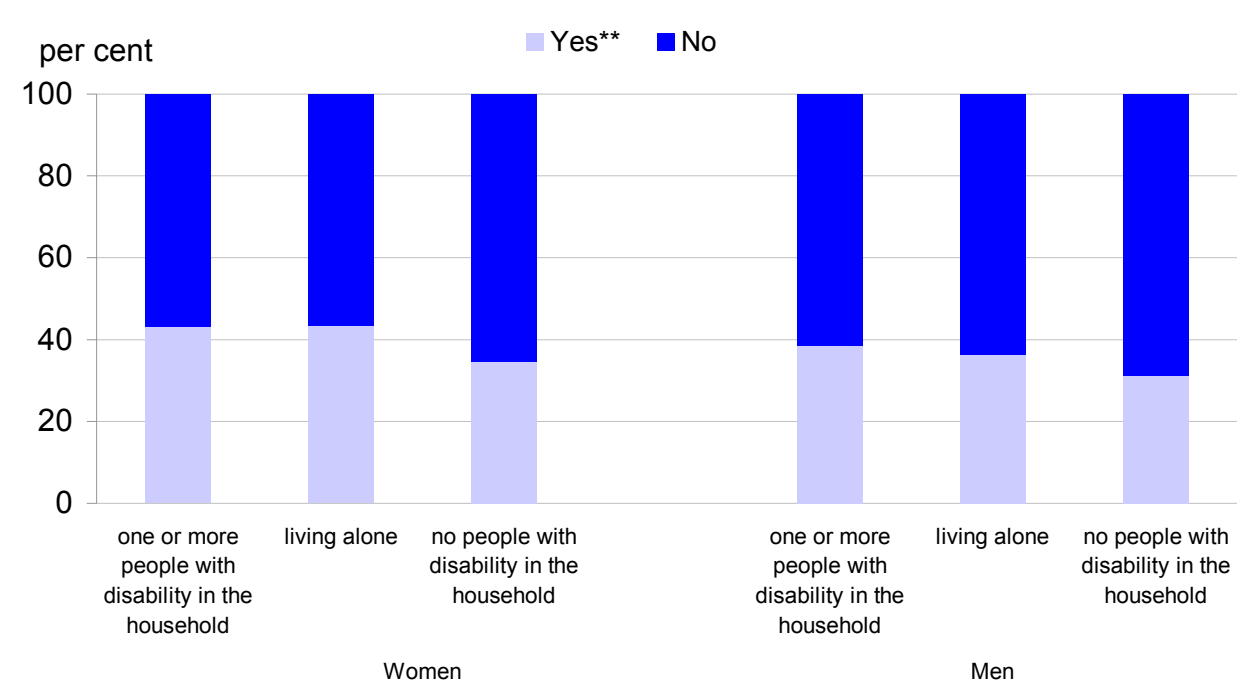

Source: ONS LS 1991 and 2001

Notes:

*Withdrawal from the labour market: refers to people who were economically active (full- or part-time employed or unemployed) in 1991 and economically inactive (because of retirement or sickness/disability or to look after family or for other reasons) in 1995

** Association between withdrawal from the labour market and presence/absence of a member of the household with long term illness at the start of the period: for women and men $p<0.001$

For the period 2002/03 to 2006/07, withdrawal from the labour market was also significantly associated with highest qualification held and labour market status at the start of the period, but it was not significantly associated with social class based on occupation.

A summary of all results of bivariate analysis of the association between withdrawal from the labour market and factors investigated in both periods is in Table 6.

The analysis of association between withdrawal from the labour market and each of the factors investigated does not allow identification of the net effect of each characteristic or circumstance on the outcome under investigation. For example, for the period 1991-1995, although withdrawal from the labour market was associated with housing tenure and ethnic group, housing tenure was also significantly associated with ethnic group. 


\section{Table $6 \quad$ Summary of results of the bivariate analysis of the association between withdrawal from the labour market and factors investigated}

\begin{tabular}{|c|c|c|c|c|}
\hline \multirow[b]{3}{*}{ Factors investigated } & \multicolumn{2}{|c|}{ Women } & \multicolumn{2}{|c|}{ Men } \\
\hline & \multicolumn{4}{|c|}{ Withdrawal from the labour market } \\
\hline & $\begin{array}{c}\text { ONS-LS } \\
1991- \\
1995\end{array}$ & $\begin{array}{c}\text { ELSA } \\
2002 / 03- \\
2006 / 07\end{array}$ & $\begin{array}{c}\text { ONS-LS } \\
1991- \\
1995\end{array}$ & $\begin{array}{c}\text { ELSA } \\
2002 / 03- \\
2006 / 07\end{array}$ \\
\hline Age & * & $*$ & * & * \\
\hline Ethnicity & * & DNA & * & DNA \\
\hline Marital status & * & * & * & NS \\
\hline Highest qualification held & * & * & * & * \\
\hline Socio-economic classification & * & NS & * & NS \\
\hline Labour market status at start of period & * & * & * & * \\
\hline Health status (self-reported) & * & * & * & NS \\
\hline Housing tenure & * & * & * & * \\
\hline Dependent child of LS member in the household & * & DNA & * & DNA \\
\hline People with long term illness in the household & * & DNA & * & DNA \\
\hline Economic activity status partner/spouse & * & DNA & * & DNA \\
\hline Region & * & DNA & * & DNA \\
\hline Caring commitments & DNA & NS & DNA & NS \\
\hline
\end{tabular}

Notes:

* Statistically significant at the 5 per cent level

$\mathrm{NS}=$ not statistically significant at the 5 per cent level

DNA = does not apply, factor not investigated in the period

\section{Withdrawal from the labour market and net impact of factors: logistic regression analysis}

To understand better the net effect of the factors that affect withdrawal from the labour market it is necessary to use multivariate regression techniques.

Table 7 shows the results of the logistic regression analysis of factors affecting withdrawal of women aged 50 to 64 in 1991 from the labour market in England and Wales in the period 19911995. Table 8 shows the results for the cohort of men of the same age who withdrew from the labour market in England and Wales in the period 1991-1995.

The tables present the odds ratios and $p$ values. The odds ratio gives a measure of the size of the effect of specific characteristics or circumstances on withdrawal from the labour market, compared with a reference characteristic or circumstance. In multiple logistic regression analysis it also gives a measure of the size of the effect of a factor when all the other factors included in the analysis are 
kept constant. $P$ values express the probability of obtaining the observed results if the new hypothesis is true.

As expected, age was by far the most significant demographic factor affecting withdrawal from the labour market for both women and men. The older people become, the more likely they are to withdraw from the labour market. However, the effect of age differs for women and men, with women more likely to withdraw over a longer time period than men.

Compared with women who were aged 50 to 54 in 1991, women aged 55 to 59 were 3.4 times more likely to have left the labour market between 1991 and 1995, whereas women aged 60 to 64 in 1991 were 5.5 times more likely to have withdrawn from the labour market in the same period (Table 7). By comparison, men aged 60 to 64 were 11 times more likely to have left the labour market compared with those aged 50 to 54 (Table 8).

Labour market status at the start of the period was another important factor that affected exit from the labour market in the period 1991-1995. Women and men who were unemployed in 1991 were 1.5 times more likely to have left the labour market in 1995 compared with those employed full-time at the start of the period. Among men the inverse was seen for those who were employed part-time at the start of the period: they were more likely to have remained economically active by 1995 , compared with those who were employed full-time at the start of the period. This trend was not seen among women.

Indian, Pakistani or Bangladeshi women were more likely to have left the labour market between 1991 and 1995 compared with White British women of the same age. Single women, women who had stated that they had a health problem at the start of the period, women whose partner or spouse was economically inactive at the start of the period, and women living in Wales and the North of England were most likely to have left the labour market in the period 1991-1995 (Table 7).

A few factors had the opposite effect; that is, they influenced women of older ages to delay their withdrawal from the labour market. Women who owned a property with a mortgage were more likely to work longer than those who owned a property outright; women who had A level, GCSE or other qualification were also more likely to work longer compared with women who had a degree or higher education (Table 7).

With a few exceptions, most factors that had an effect on withdrawal of women from the labour market between 1991 and 1995 also affected withdrawal of men from the labour market in the same period. For men a few factors were influential in the opposite direction: working part-time at the start of the period and privately renting a house were factors that significantly contributed to men staying longer in the labour market (Table 8). 


\section{Table $7 \quad$ Logistic regression analysis of factors affecting withdrawal from the labour market between 1991 and 1995 for women aged 50 to 64 in 1991, England and Wales}

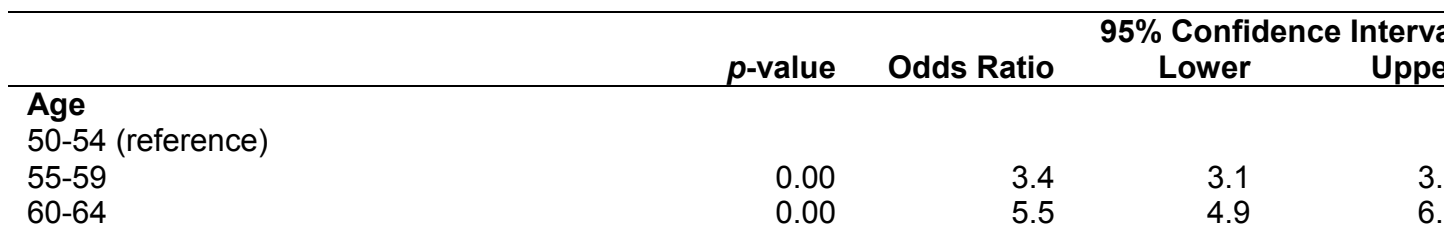

Ethnicity

White British (reference)

Irish and Other White

0.05

0.33

0.00

0.8

0.9

Indian, Pakistani, Bangladeshi

1.7

0.7

0.6

1.2

1.0

Marital status

married/re-married (reference)

single

0.00

0.05

1.6

0.8

1.3

0.7

0.8

3.7
6.2

widow

0.60

0.9

1.0

Highest qualification held

Degree or higher education (reference)

A level, GCSE or Other qualification

0.00

0.23

0.8

0.7

0.8

0.9

No qualification

0.9

1.1

Socio-economic classification

Managerial \& Professional (reference)

Intermediate

0.00

0.02

1.3

1.2

1.0

1.4

Routine \& Manual occupations

1.1

Labour market status at start of period

employed full time (reference)

employed part time

0.53

1.0

0.9

1.1

unemployed

0.00

1.5

1.2

1.9

Health status (self-reported)

No health problem (reference)

Has a health problem

0.00

1.5

1.3

1.8

Housing tenure

Own outright (reference)

Own with mortgage

0.00

0.09

0.8

0.8

0.7

0.9

0.9

0.54

0.9
1.0

1.0

Rent from local authority/housing association

1.2

Dependent child of LS member in the household

Yes (reference)

No

0.00

2.1

1.7

2.6

No partner/spouse/child in the household

0.00

2.1

1.3

3.3

Economic activity status partner/spouse

Economically active (reference)

Economically inactive

0.00

1.4

1.3

1.6

No partner/spouse in the household

0.98

1.0

0.6

1.7

\section{Region}

South, East \& Midlands (reference)

North of England \& Wales

0.00

1.3

1.2

1.4

Source: ONS LS 1991 and 2001

Notes:

$p$ values less than .05 denotes statistical significance at the 5 per cent level 
Odds Ratio: gives a measure of the size of the effect that specific categories of the factors investigated have on withdrawal from the labour market compared with a reference category of the same factor. An odds ratio greater than 1 means that the factor under investigation increases the chance of the outcome occurring. An odds ratio less than 1 means that the factor under investigation decreases the chance of the outcome occurring. An odds ratio equal to 1 means that the factor does not affect the outcome.

Pseudo R-Square: (Nagelkerke) $=0.183$; Goodness-of-Fit: Pearson Chi square $p=0.115$

\section{Table $8 \quad$ Logistic regression analysis of factors affecting withdrawal from the labour market between 1991 and 1995 for men aged 50 to 64 in 1991, England and Wales}

\begin{tabular}{|c|c|c|c|c|}
\hline & \multirow[b]{2}{*}{$p$-value } & \multirow[b]{2}{*}{ Odds Ratio } & \multicolumn{2}{|c|}{ 95\% Confidence Interval } \\
\hline & & & Lower & Upper \\
\hline \multicolumn{5}{|l|}{ Age } \\
\hline \multicolumn{5}{|l|}{ 50-54 (reference) } \\
\hline $55-59$ & 0.00 & 2.9 & 2.7 & 3.1 \\
\hline $60-64$ & 0.00 & 11.0 & 10.1 & 12.0 \\
\hline \multicolumn{5}{|l|}{$\begin{array}{l}\text { Socio-economic classification } \\
\text { Managerial \& Professional (reference) }\end{array}$} \\
\hline Intermediate & 0.00 & 1.2 & 1.1 & 1.4 \\
\hline Routine \& Manual occupations & 0.00 & 1.2 & 1.1 & 1.3 \\
\hline \multicolumn{5}{|l|}{ Labour market status } \\
\hline employed part time & 0.00 & 0.7 & 0.6 & 0.9 \\
\hline unemployed & 0.00 & 1.5 & 1.3 & 1.7 \\
\hline \multicolumn{5}{|l|}{ Health status (self-reported) } \\
\hline \multicolumn{5}{|l|}{ No health problem (reference) } \\
\hline Has a health problem & 0.00 & 1.9 & 1.7 & 2.1 \\
\hline \multicolumn{5}{|l|}{ Housing tenure } \\
\hline \multicolumn{5}{|l|}{ Own outright (reference) } \\
\hline Own with mortgage & 0.03 & 0.9 & 0.9 & 1.0 \\
\hline Rent privately & 0.00 & 0.7 & 0.6 & 0.9 \\
\hline Rent from local authority/housing association & 0.19 & 1.1 & 1.0 & 1.2 \\
\hline \multicolumn{5}{|c|}{$\begin{array}{l}\text { Dependent child of LS member in the household } \\
\text { Yes (reference) }\end{array}$} \\
\hline No & 0.00 & 1.4 & 1.3 & 1.6 \\
\hline No partner/spouse/child in the household & 0.00 & 2.8 & 1.6 & 5.1 \\
\hline \multicolumn{5}{|l|}{$\begin{array}{l}\text { Economic activity status partner/spouse } \\
\text { Economically active (reference) }\end{array}$} \\
\hline Economically inactive & 0.00 & 1.4 & 1.3 & 1.5 \\
\hline No partner/spouse in the household & 0.13 & 0.6 & 0.3 & 1.1 \\
\hline \multicolumn{5}{|l|}{$\begin{array}{l}\text { Region } \\
\text { South, East \& Midlands (reference) }\end{array}$} \\
\hline North of England \& Wales & 0.00 & 1.4 & 1.3 & 1.5 \\
\hline
\end{tabular}

Source: ONS LS 1991 and 2001

Notes:

p values less than .05 denotes statistical significance at the 5 per cent level

Odds Ratio: gives a measure of the size of the effect that specific categories of the factors investigated have on withdrawal from the labour market compared with a reference category of the same factor. An odds ratio greater than 1 means that the factor under investigation increases the chance of the outcome occurring. An odds ratio less than 1 means that the factor under investigation decreases the chance of the outcome occurring. An odds ratio equal to 1 means that the factor does not affect the outcome.

Pseudo R-Square (Nagelkerke) = 0.256; Goodness-of-Fit: Pearson Chi square $p<0.001$ 


\section{Table $9 \quad$ Logistic regression analysis of factors affecting withdrawal from the labour market between $2002 / 03$ and 2006/07 for women and men aged 50 to 64 in 2002/03, England}

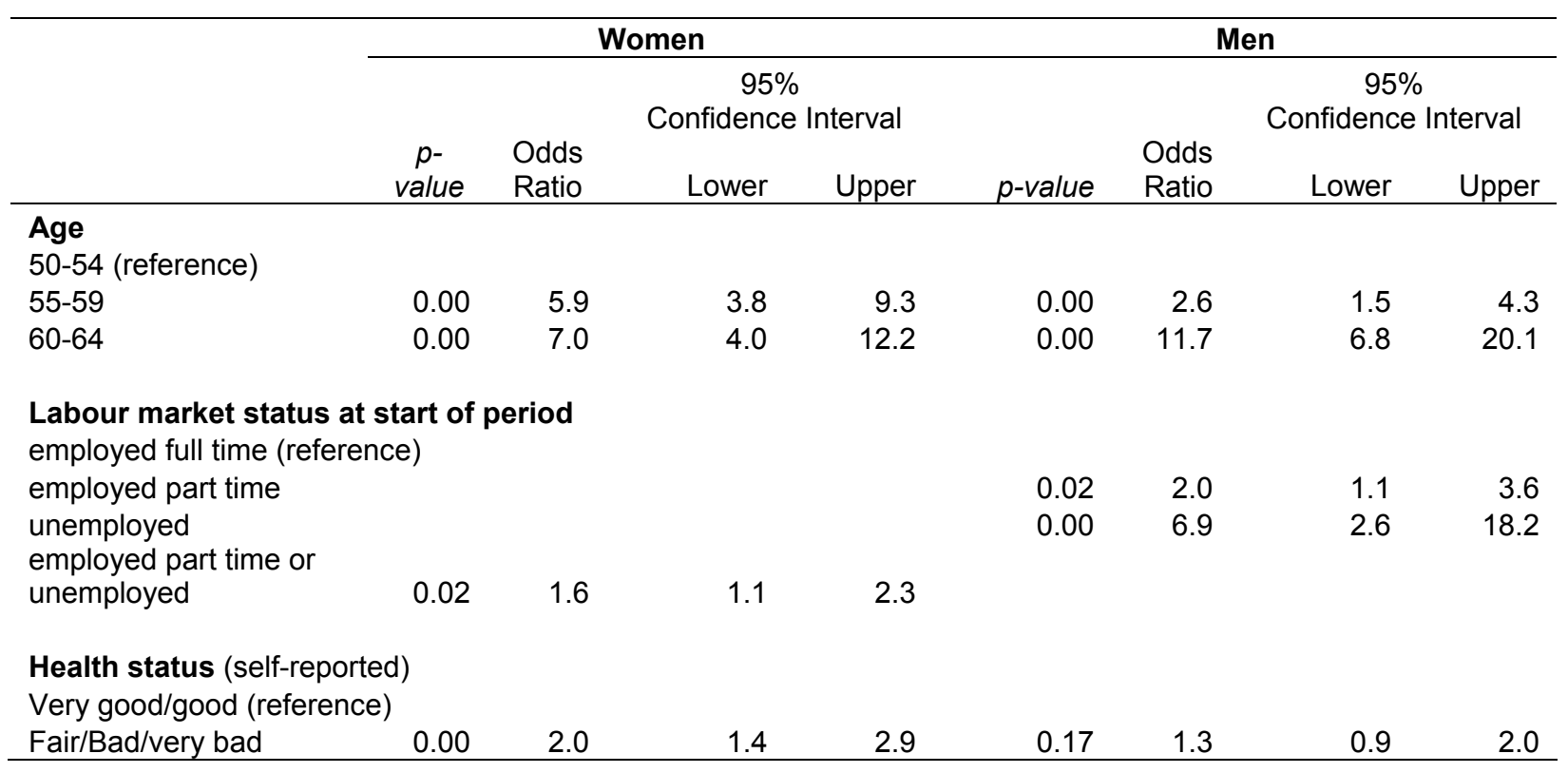

\section{Source: ELSA 2002/03 and 2006/07}

Notes:

$p$ value less than 0.05 denotes statistical significance at the 5 per cent level

Odds Ratio: gives a measure of the size of the effect that specific categories of the factors investigated, compared to a reference category of the same factor, affect withdrawal from the labour market. An odds ratio greater than 1 means that the factor under investigation increases the chance of the outcome occurring. An odds ratio less than 1 means that the factor under investigation decreases the chance of the outcome occurring. An odds ratio equal to 1 means that the factor does not affect the outcome.

Pseudo R-Square (Nagelkerke): for women $=0.228$; for $\operatorname{men}=0.246$

Goodness-of-Fit: Pearson Chi square for women $p=0.244$; for men $p=0.595$

Table 9 shows the results of the logistic regression analysis of the factors that significantly affected the withdrawal from the labour market of both women and men aged 50 to 64 in England at the start of the 21st century. Age, labour market status and self-reported health status at the start of the period significantly affected withdrawal of older workers from the labour market between 2002/03 and 2006/07.

Common factors that were found to affect withdrawal of older workers from the labour market in both periods were older age, unemployment and poor health. In both periods older age was the most important factor affecting withdrawal from the labour market for both women and men.

Among women, unemployment and poor health had similar relative impact in the withdrawal from labour market in both periods. For men, being unemployed at the start of the period had a relatively greater impact in exiting the labour market in the beginning of the 21 st century than in the early 1990s.

Sample sizes vary greatly between the two data sources and the factors used in each period of analysis differ. Interpretation of the relative impact of factors that affect withdrawal from the labour market in each period investigated should be made with caution. 


\section{Conclusions}

The factors that impact on people's employment at older ages are complex. People's decisions to extend their working lives beyond SPA seem to be more affected by factors such as age, health, accumulated wealth, pension arrangements, caring commitments and, although less often investigated, by earlier life events such as age of entry into the labour market, working-life history and age of family formation $5^{5} 78$. Labour market circumstances and retirement policy are also factors affecting older workers' decisions about their later working lives.

Older workers at the beginning of the 21st century had extended working lives compared with those in the early 1990s. The analyses show that the percentage of older workers aged 50 to 64 in $2002 / 03$, who left the labour market between 2002/03 and 2006/07, was lower than the percentage of people of the same age who had left the labour market about a decade earlier.

Although the working lives of the 21st century cohort are extended in comparison with those of the 1990s cohort, age, unemployment and poor health remain significant factors that impact on older workers' withdrawal from the labour market at the beginning of the 21 st century.

The increase in employment rates of adults of older ages in the UK over the past 15 years coincided with the period of economic growth since mid 1990s. Despite the recent economic downturn, the employment rates for adults of older ages has remained stable from mid-2008 up to the first quarter of $2010^{9}$. The impact of the economic recession on future unemployment of older workers is still uncertain and may vary between different sub-groups.

Between 2010 and 2020 the SPA for women will gradually increase from 60 to 65 and between 2024 and 2046 the SPA for both women and men will increase to 68 years. The Government has recently announced a review of the timing of the increase in SPA to 66 years ${ }^{10}$. The increase in SPA may encourage people to extend their working lives, and so build up savings and contributions to fund their retirement. An increase in working life expectancy, however, depends on labour market demand and on the availability of flexible jobs to enable older workers to accommodate demands of other commitments such as informal care.

Health greatly impacts on the withdrawal of older workers from the labour market. In the first quarter of 2010, two-fifths of women and a quarter of men aged 50 to 64 were economically inactive. Among these, half of the men were inactive because of sickness or disability and half of the women because of sickness or disability or to look after family. Although both life expectancy and healthy life expectancy have increased, life expectancy has increased at a faster rate. Having a population of older workers in good health is essential to the increase in people's working life expectancy ${ }^{11}$.

Research and statistics play a central role in providing information for monitoring policies on employment, unemployment and inactivity at older ages. ONS reports periodically on trends in labour market participation and transition from work to retirement ${ }^{12}$. ONS has recently developed and published a new method to estimate the duration of working life and the average age of withdrawal from the labour market ${ }^{13}$. 


\section{Key findings}

- The percentage of women and men who withdrew from the labour market increased with age; this was observed in both periods investigated, 1991 to 1995 and 2002/03 to 2006/07

- The percentage of both women and men aged 50 to 54,55 to 59 and 60 to 64 in 2002/03 who withdrew from the labour market between 2002/03 and 2006/07 was lower than the percentage of people of the same age who left the labour market between 1991 and 1995 for each of the age groups

- Logistic regression analysis of the factors likely to affect withdrawal from the labour market of women aged 50 to 64 in 1991 showed that Indian, Pakistani or Bangladeshi; single women; women who had stated having a health problem at the start of the period; women whose partner or spouse was economically inactive at the start of the period and women living in the North of England or Wales were more likely to withdraw from the labour market between 1991 and 1995

- Between 1991 and 1995, women who owned their homes with a mortgage and women who had A level, GCSE or other qualifications were more likely to stay in the labour market for longer

- With a few exceptions, most factors that affected withdrawal of women aged 50 to 64 in 1991 from the labour market between 1991 and 1995 also affected withdrawal of men of the same age from the labour market in the same period

- Age, labour market status and health status at the start of the period significantly affected withdrawal of older workers from the labour market in the beginning of the 21 st century

- The common factors affecting withdrawal from the labour market in the two periods investigated were age, unemployment and poor health. People in older age groups, people who were unemployed and those in poor health at the start of the period were more likely to have left the labour market.

\section{ANNEX 1}

\section{ONS Longitudinal Study and method used in analysis}

The ONS Longitudinal Study (ONS LS) contains linked census and vital event data for one per cent of the population of England and Wales. Information from the 1971, 1981, 1991 and 2001 censuses is linked with life events information (that is, LS members' birth, death and cancer registration). Sample selection is based on four dates of birth to create a sample which is representative of the population of England and Wales.

For the analysis, ONS LS members aged 50 to 64 in 1991 living in households enumerated and traced in 1991 and 2001 censuses were initially selected. LS members who in the 2001 Census were exactly 10 years older than the age declared in the 1991 Census were included in the analysis. 
The ONS LS contains census information for people who are enumerated in the same household as the ONS LS member. This information was used to investigate the family contexts likely to affect changes in economic activity status of LS members. The information on people enumerated at the same private address as the LS member is not linked through time.

The ONS LS shares some of the limitations of the census, one of its data sources. For instance, the census information is collected once every ten years and it mostly relates to people's circumstances at the time.

\section{Economic activity status in the 1991 Census}

In 1991 a single multi-response question was asked to determine if people aged 16 or over were economically active or inactive, and why. People's economic activity status in the week before the census was recorded as:

- Economically active: employees - full-time; employees - part-time; self-employed with employees; self-employed without employees; on a Government scheme; waiting to start a job; unemployed

- Economically inactive: students; retired; permanently sick; looking after home/family; other inactive.

For the analysis, the 1991 Census categories of economic activity were used.

\section{Economic activity status in the 2001 Census}

In 2001 a series of questions were asked of those aged 16 to 74 (including full-time students) to enable statistics to be derived that are compatible with the International Labour Organisation (ILO) definition of economic activity status. In contrast to 1991, information on part-time/full-time status was not an integral part of these questions. A separate question on hours worked was asked.

The 2001 Census derived variable of economic activity status was used for the analysis.

Categories were aggregated into 'economically active' (employee or self-employed working full- or part-time and unemployed) and 'economically inactive' (retired, permanently sick/disabled, looking after home/family, other). Students who had also reported themselves as an employee, employed or unemployed were classified as economically active; students who had reported themselves as inactive were coded as economically inactive.

The definitions of some of the categories within economic activity and inactivity changed slightly from 1991 to 2001 . The main differences were:

- 'Unemployed': in 2001 the ILO definition was used for unemployment. In 1991 any person not currently working who was seeking work, prevented by temporary sickness from seeking work or waiting to take up a job already accepted were considered unemployed.

- Unpaid work: in 1991 persons in unpaid work (other than those in a family business including a shop or farm) were included under 'economically inactive: other'. In 2001 they are included under 'in employment' and classified according to the person's responses to the questions.

- Economically inactive - 'student': although the 1991 Census form included a separate box for people to indicate that they were a 'student' in the question on activity in the week before the census, the 'economically inactive - student' category was created in output and included all fulltime students, irrespective of their indicated economic status from other information recorded on 
the form. In 2001, the category includes economically inactive full-time students and part-time students who did not give any other reason for economic inactivity.

Less than 0.05 per cent of the sample of people aged 50 to 64 included in this analysis had been recorded as students in the 1991 Census.

\section{Demographic and socio-economic characteristics, health status, housing and household circumstances}

With the exception of 'ethnicity' and 'highest qualification held', all other explanatory variables used in the analysis were based on the circumstances of ONS LS members or non-LS members of the household as at Census Day 1991.

Ethnicity: ethnic group as given by the 2001 Census was used in the analysis. Because of small sample sizes in some of the categories, ethnic groups were combined in four categories: (1) Indian, Pakistani and Bangladeshi, (2) Black Caribbean, Black African, Other Black, White and Black Caribbean, White and Black African, White and Asian, Other Mixed, Chinese, Other Asian and Other Ethnic groups, (3) White Irish and Other White and (4) White British.

Legal marital status categories in the 1991 Census were single, married (first marriage), remarried, divorced and widowed. People who were separated but not divorced were asked to complete the census form as 'married (first marriage)' or 'remarried', if appropriate. For the analysis categories married and remarried were combined; all other categories were used as given by the census.

Highest qualification held as given by the 2001 Census was used in the analysis. This is because the 1991 Census collected information on degrees, professional or vocational qualifications attained; information on school-level qualifications was not collected. In 2001 the census question recorded broad groupings of school level, degree and vocational qualifications relevant to each country (and specific professional qualifications in England and Wales). For the analysis highest qualification held categories were combined as (1) no qualification, (2) A level, GCSE and other qualification and (3) degree or equivalent or higher education.

Social class based on occupation: in the 1991 Census, people with a paid job were assigned to a social class by reference to their occupation in the week preceding the census or, where there was no paid job, on the basis of the most recent paid job held within the previous ten years. Members of the armed forces, those with inadequately described occupations and people on a government employment or training scheme were not allocated to a social class. For the analysis, categories were aggregated as (1) Routine and manual occupation, (2) Intermediate occupation and (3) Managerial and professional occupation. Members who had not been allocated social class classification were excluded from the analysis.

Labour market status at start of the period was derived using the information on economic activity status given by the 1991 Census. The categories used were employed full-time, employed part-time, and unemployed. People classed as self-employed with or without employees or on a government scheme were considered full-time employed. Exploratory analysis of economic activity status and hours usually worked per week in a person's main job showed that about 80 per cent of 
people aged 50 to 64 who had reported themselves as self-employed with or without employees worked 30 or more hours per week.

Housing tenure: the original categories of housing tenure used in the 1991 Census in England and Wales were: owner occupier (1) with mortgage, (2) outright; rent, rent free or lease (3) with job, farm, shop or other business, (4) from local authority (council), (5) from new town development corporation or housing action trust, (6) from housing association or charitable trust, (7) from a private landlord furnished, (8) from a private landlord unfurnished.

For the analysis, categories 3,7 and 8 were aggregated as 'renting privately', categories 4,5 and 6 were aggregated as 'renting from local authority/housing association'; the other original 1991 Census categories were maintained as they were.

Self-reported health status: the 1991 Census question 'Does the person have any long-term illness, health problem or handicap which limits his/her daily activities or the work he/she can do?' was used for analysis of people who had or did not have a health problem.

Presence/absence of dependent child/children in the household: the 1991 ONS LS derived variable 'Minimal household unit type' was used for information on ONS LS members living in a household with or without their dependent child/children or living in a household with no spouse, partner or dependent child/children. For the analysis, people were classed as living with dependent child/children if they were living as 'lone parent with dependent children' or 'married couple with dependent children' or 'cohabiting couple with dependent children'. People were classed as living with no dependent child/children if they were living as 'Ione parent with no dependent children' or 'married couple with no dependent children' or 'cohabiting couple with no dependent children'. The category 'Non-married individuals' from the variable 'Minimal household unit type' was used to classify ONS LS member as 'living in a household with no partner, spouse or dependent child/children'; this does not imply that these people were living alone.

Presence/absence of a member of the household with long-term illness: ONS LS variables that contain information on the relationship of ONS LS member with non-ONS LS members (living in the same household) and their health status were used to derive a variable for presence of a child/children, spouse/partner, parent or any other person in the household with long-term illness. The categories of the derived variable used in the analysis were 'one or more people with longterm illness in the household', 'living alone' and 'no people with long-term illness in the household'.

Economic activity status of spouse/partner: ONS LS variables that contain information on the relationship of LS members with non-ONS LS members (living in the same household) and their economic activity status were used to derive a variable for the economic activity status of the spouse/partner of the ONS LS member. The categories of economic activity status used in the analysis were 'economically active' and 'economically inactive' (as detailed under item 'economic activity status in the 1991 Census' described previously).

Government Office Region/UK country of usual residence: for the analysis original regions/country of usual residence as at the 1991 Census Day were aggregated into two categories: (1) 'North of England and Wales' (which included the English regions of North East, North West, Yorkshire and the Humber and Wales) and (2) 'South, East and Midlands' (which 
included the regions of East Midlands, West Midlands, East of England, London, South East and South West).

\section{ANNEX 2}

\section{English Longitudinal Study of Ageing (ELSA)}

The English Longitudinal Study of Ageing (ELSA) started in 2002 as a study of people aged 50 and over and their partners, living in private households in England. Every two years the same group of people are interviewed to measure changes in their health, economic and social circumstances. ELSA uses the Health Survey for England (HSE) as the sampling frame. In 2006, the study included a refreshment sample of people aged between 50 and 53 who were living within households that took part in the HSE 2001 to 2004 . More information about ELSA is available at www.ifs.org.uk/elsa/

This analysis included ELSA core members aged 50 to 64 in 2002/03 who had also participated in the $2006 / 07$ follow up study.

\section{Economic activity status in 2002/03 and 2006/07}

A set of questions asked in ELSA 'Work and Pensions' modules in Waves 1 and 3 were used to derive variables that best approximated the International Labour Organisation (ILO) and Labour Force Survey definition of economic activity and inactivity. Detailed information for the ELSA questions used to derive the economic activity status was highlighted in an earlier article ${ }^{14}$.

Definitions of economic activity and inactivity status in Waves 1 and 3 were compatible. For the analysis, people were defined as being economically active if either they reported being in full-time or part-time paid employment or self-employment at the time of interview (including those temporarily away from their usual employment), or if they reported being unemployed. People were classified as being economically inactive if they reported being inactive because of retirement or sickness/disability or to look after family or for other reasons.

\section{Demographic and socio-economic characteristics, health status, housing and caring commitments}

All explanatory variables were derived on the basis of people's circumstances in 2002/03.

Marital status: categories used in the analysis were single, married, divorced/separated and widowed.

Educational qualifications: in the analysis, people were divided into three educational groups, depending on whether they reported having 'degree or equivalent or higher education', 'A levels, GCSE or other qualification' or 'no qualification'.

Socio-economic status: ELSA NS Socio Economic Classification categories were used to derive a variable for economic activity status of people included in the sample. The aggregated categories 'managerial and professional occupations', 'intermediate' and 'routine and manual occupations' were used in the analysis. 
Labour market status at the start of the period was given by the derived variable for the economic activity status in 2002/03. People were considered 'employed full-time' if they reported working at least 30 hours a week in employment or self-employment. Sample size of women in category 'unemployed' were very small; therefore, in the logistic regression analysis this category was combined with the category 'employed part time'.

Self-reported health status: respondents to ELSA were asked to rate their current health status on a five-point scale: very good, good, fair, bad and very bad. For the purposes of this analysis, responses were aggregated into two categories: 'very good or good' and 'fair, bad or very bad'.

Housing tenure was based on the household tenure of the respondent. For the purpose of this analysis, housing tenure was divided into three categories, those who own the property they live in outright, those who were purchasing the property with a mortgage (including shared ownership schemes), and those who were renting (including those living rent-free in property they do not own and people who were squatting).

Caring commitments: in ELSA, carers are self-defined, that is, respondents describe themselves as 'looking after someone' in the past week. In the analysis, people were classified as having caring responsibilities in the week prior to being interviewed if they answered 'yes' to the question 'Did you look after anyone in the past week (including your partner or other people in your household)?'

\section{ANNEX 3}

\section{Differences between ONS LS and ELSA data sources}

1. ONS LS data includes people living in communal establishments. For this investigation only individuals resident in private households were included.

2. Sample sizes are different. ONS LS sample sizes are larger than in ELSA. For the analysis ELSA categories that had very small sample sizes were combined where appropriate.

3. ONS LS sample comprises people living in England and Wales and ELSA sample includes people living in England. As a check, analysis was conducted using ONS LS members living in households in England only. The results did not show significant differences from those obtained from analysis including people living in England and Wales.

4. About 10 to 15 per cent of some of the characteristics of the ONS LS sample from the 2001 Census contained item imputation (imputation means that a value has been assigned to a specific data item where the response was missing or unusable). Analysis was conducted using ONS LS data excluding people who had had any item imputed. The results did not show significant differences from the analysis that included people where some of the characteristics were imputed. ELSA data used in this analysis did not contain imputed items.

5. ONS LS sample of people who were economically active or inactive at the end of the period between 1991 and 1995 was derived from information from the 1991 and 2001 censuses. Data on withdrawal from the labour market in this period was from a proxy derived using data 
from 2001 Census. Therefore, it relied on people surviving to the 2001 Census. Information on withdrawal from the labour market given by ELSA did not rely on prospective data.

6. The 1991 Census and ELSA 2002/03 questions on health status are worded differently. The census question asked if a person had any long-term illness, health problem or handicap which limited his/her daily activities or the work he/she could do. The choices of answers were 'yes' or 'no'.

Respondents to ELSA were asked to rate their current health status on a five-point scale: very good, good, fair, bad and very bad. For this investigation ELSA responses were aggregated into two categories 'fair, bad or very bad' and 'very good or good'.

Census and ELSA questions on health measure different dimensions of health status and are therefore not directly comparable. These differences should be taken into account in the interpretation of the results.

\section{Acknowledgements}

The author would like to thank all those who commented on this article and the members of the ONS LS team for their assistance with this project.

\section{References}

1 Office for National Statistics (2009) 'Ageing - ensuring research and statistics meet the needs of a changing society'. Population Trends 136, p 4-5.

2 Blackwell L, Lynch K, Smith J and Goldblatt P(2003) ONS Longitudinal Study 1971-2001: Completeness of Census Linkage. Series LS nr 10. Office for National Statistics: London.

3 Institute for Fiscal Studies (2009) Information on English Longitudinal Study of Ageing. Available at: http://www.ifs.org.uk/elsa/index.php

4 Office for National Statistics (2010) Information on health expectancy. Available at: www.statistics.gov.uk/cci/nugget.asp?id=934

5 Phillipson C and Smith A (2005) Extending working life: a review of the research literature. Department for Work and Pensions. DWP Research Report No. 299.

6 Banks J and Tetlow G (2008) ‘Extending working lives'. In: Banks J, Breeze E, Lessof C and Nazroo J (eds) Living in the 21st century: older people in England: The 2006 English Longitudinal Study of Ageing (Wave3). Institute for Fiscal Studies: London, pp 19-56.

7 Vickerstaff S, Loretto W, Billings J, et al (2008) Encouraging labour market activity among 60-64 year olds. Department for Work and Pensions. DWP Research Report No 531.

8 Blekesaune M, Bryan M and Taylor M (2008) Life-course events and later-life employment. Department for Work and Pensions. DWP Research Report No 502. 
9 Office for National Statistics (2010) Information on labour market. Available at: www.statistics.gov.uk/downloads/theme labour/LMS FR HS/WebTable02.xls

10 On 24 June 2010 the Government announced a review into the timing of the increase in State Pension age to 66. To support this review the Government published a call for evidence to inform an internal review. The call for evidence closed on 6 August 2010 and the response is to be published in the autumn. More information available at: www.dwp.gov.uk/policy/pensions-reform/latest-news/\#call

11 Mayhew $L$ (2010) Increasing longevity and the economic value of healthy ageing and working longer. Cass Business School. City University London. A summary of the report is available at: www.ilcuk.org.uk/index.jsp

12 Office for National Statistics (2010) 'The labour market and retirement'. Pension Trends. Available at: www.statistics.gov.uk/pensiontrends/

13 Office for National Statistics (2010) 'Average age of withdrawal from the labour market'. Pension Trends. Available at: www.statistics.gov.uk/pensiontrends/

14 Dini E (2009) 'Older workers in the UK: variations in economic activity status by socioeconomic characteristics, household and caring commitments'. Population Trends 137, p 1124. 